\title{
Are Firms in Corporate Groups More Resilient During an Economic Crisis? Evidence from the Manufacturing Sector in Poland
}

\author{
Barbara Jankowska', Katarzyna Mroczek- \\ Dq̨browska ${ }^{2}$, Marian Gorynia ${ }^{3}$ \\ and Marlena Dzikowska ${ }^{4}$
}

\begin{abstract}
Corporate groups are specific types of business networks that generate particular advantages for firms. They allow corporates to reduce costs, develop the pool of resources and increase the flexibility of operations and responses to external shocks among others. The above mentioned benefits are of even greater importance during times of economic turbulence. Their involvement in a corporate group should theoretically allow firms to perform better. The aim of this study is to verify whether corporate group membership truly translated into a firm's higher input competitiveness and a firm's better performance during the recent economic crisis. First, we try to investigate if the input competitiveness is higher in the case of firms being members of corporate groups. Second, we test whether the involvement in a corporate group matters for the performance of the firms. Using critical in-depth literature studies and conducting the primary empirical research using the CATI (computer-assisted telephone interviewing) method we strive to verify the following hypothesis - the higher a company's input competitiveness during the economic crisis, the better a competitive position the company achieves. The empirical research encompasses more than 700 corporates from the manufacturing sector in Poland during the global economic crisis

1 Barbara Jankowska, Associate Professor, Poznań University of Economics and Business, Department of International Competitiveness, al. Niepodległości 10, 61-875 Poznań, Poland. E-mail: barbara.jankowska@ue.poznan.pl.

2 Katarzyna Mroczek-Dąbrowska, Assistant Professor, Poznań University of Economics and Business, Department of International Competitiveness, al. Niepodległości 10,61-875 Poznań, Poland. E-mail: katarzyna.mroczek@ue.poznan.pl. 3 Marian Gorynia, Professor, Poznań University of Economics and Business, Department of International Competitiveness, al. Niepodległości 10, 61-875 Poznań, Poland. E-mail: m.gorynia@ue.poznan.pl, al.

4 Marlena Dzikowska, Assistant Professor, Poznań University of Economics and Business, Department of International Competitiveness, al. Niepodległości 10,61-875 Poznań, Poland. E-mail: Marlena.dzikowska@ue.poznan.pl.
\end{abstract}


and shortly afterwards. To investigate the issue we use the following methods of statistical analysis - cluster analysis, non-parametric tests and correlation coefficients. The results of the study show that firms involved in both Polish and international corporate groups were more resilient during the economic crisis than those which were not.

Keywords: corporate groups, economic crisis, performance, networking.

\section{INTRODUCTION}

An economic crisis in the simplest terms is a sharp drop in the economic activity that manifests itself through decreasing GDP, increasing unemployment, decreasing investment activity, turbulent financial markets and increasing factor costs. Gourinchas and Kose (2011) pointed to the fact that the financial crisis that started in 2008 led to the deepest and most synchronized global recession over the past 70 years. According to World Development Forum, the GDP growth in Poland achieved a level of $2.63 \%$ in 2009 compared to $-4.39 \%$ for the European Union (World Development Indicators, 2015). This ability to cope with the economic crisis gave Poland the name "Green Island". In the next few years the GDP growth in Poland was even higher reaching the level of $5.01 \%$ in 2011 and $1.3 \%$ in 2013, respectively. The comparatively strong results of the Polish economy reflect the relatively high immunity of Polish firms to economic crisis turbulence. Still, the manufacturing companies that accounted for around 10\% of the registered entities in Poland in 2009 and 2011 dropped to little more than $9 \%$ in 2013. They employed about $27 \%$ of the workforce in the period 2009-2013. The industry value added amounted to PLN 240 billion in 2009 and almost PLN 270 billion in 2011 and 2013. Many of the companies present in the industry were the firms affiliated within corporate groups.

A corporate group "(...) is composed of corporates that are independent in legal terms, but rely on each other economically due to the control and/ or ownership links between them. Within a group, some links between a dominant entity (parent) and its subsidiaries are distinguished" (CSOP, 2015, p. 18). The Central Statistical Office in Poland (CSOP) uses the term enterprise group instead of corporate group but in literature they are used interchangeably. According to the survey conducted annually by CSOP, there are more than 2000 corporate groups registered in Poland. Most of them operate in manufacturing industries and trade and repair of motor vehicles. Throughout 2009-2013 these two areas of economic activities accounted for about $46 \%$ of people employed in corporate groups. To be more specific corporate groups can be further divided into: "(1) all-resident corporate group composed only of corporates (both group head and subsidiaries) that are all 
resident in the same country; (2) multinational corporate group composed of at least two corporates located in different countries; (3) truncated corporate group as a part of a multinational group, located in the same country" (CSOP, 2015).

All-resident groups constituted about $50 \%$ of all registered groups in 2009, in 2010 the share of all-resident groups in the number of all registered groups dropped to 41\%, in 2011 to 36\%, in 2012 and 2013 to 31\%. Overall, the statistics on the corporate groups have not changed much through the analyzed period $2009-2013$. They account for $0.6 \%$ of all the non-financial firms registered in Poland but employ about $28 \%$ of all employees and generate more than $50 \%$ of the sales income. The corporate groups that operate internationally (foreign controlled truncated corporate groups) mostly had their headquarters located in EU Member States. Throughout 20092013 Germany was the number one location, followed by the Netherlands (2009-2011) and most recently Cyprus (2014). Outside the EU zone the United States was the main global group headquarters (CSOP, 2010, 2011, $2012,2013,2014,2015$ ). Most of the corporate groups (in the manufacturing sector) employ between 50 and 249 people (153 groups) or more than 1000 people (122 groups). In total that accounts for almost 500,000 employees. Their total assets come to PLN 202.85 billion with $58 \%$ in fixed assets and the remaining $42 \%$ in current assets.

Bearing in mind the significant position of corporate groups in Poland during the economic crisis and shortly afterwards, our aim is to verify whether members of corporate groups in Poland performed better than companies outside such groups. Using the CATI method, we conducted a survey of 695 manufacturing companies to gather information on their performance during the period 2009-2013. Afterwards, the information was supplemented by relevant financial data extracted from the Amadeus database. Detailed information on the indicators used is provided in later sections.

We start our paper by outlining the conceptual background behind corporate groups, how they are perceived as a specific type of business network, and how they use their resources and capabilities as sources of competitive advantage. We then use existing literature to formulate hypotheses related to the interdependencies between corporate group affiliation and sources of competitive advantage and separately between corporate group affiliation and their performance. Subsequently, we present the methodology and the findings of the analysis with the use of descriptive statistics, non-parametric analysis of variance and correlation coefficients. In the final part of the paper, we discuss the findings and highlight the implications and limitations of our research. 


\section{CONCEPTUAL BACKGROUND AND HYPOTHESES DEVELOPMENT}

\section{Corporate group affiliated firms' sources of advantages}

The emergence of corporate groups has played a significant role in the globalization process, and currently these groups play a vital role in the transformation of both Eastern European and Asian countries. A corporate group, known also as an enterprise group (CSOP, 2015) or a business group (Carney, 2011), consists of independent economic entities that are bound together through capital, transactional and personal ties (Romanowska, 2011). The concept of corporate groups differs across nations. In Poland, as mentioned before, the definition was formulated by the CSOP (2015). Though a significant growth in the number of corporate groups can be mainly observed in the developing countries, they are also of great significance in the developed ones. A quick look at the trade flows reveals that $75 \%$ of US trade is directly linked to corporate groups and similarly $65 \%$ of French international trade is carried out by domestic or foreign-owned corporate groups (Altomonte \& Rungi, 2013). Thus, the importance of such groups should not be underestimated.

Corporate groups come into existence through mergers and acquisitions, capital outsourcing, direct investments and consolidation (Trocki, 2004). They can be viewed as a neo-institution that emerges from the network of firms filling the institutional voids (e.g., Li \& Kozikode, 2008).

Corporate groups are said to be set between markets and hierarchies (Williamson, 1975, 1985). These co-dependent entities create structures that vary both in terms of organization and management. Corporate groups created through capital outsourcing (that is extracted from an already existing firm that belongs to the group) tend to be homogenous throughout. Control does not have to be exerted in excess as strong ties exist between the old and new firms in the group. Much more control is needed in the case of groups that come into existence by mergers and acquisitions (Trocki, 2004). As firms vary in cultural, organizational, social and sometimes even ethical ways, a common ground (i.e. common rules of conduct) needs to be established to create a networking platform for the companies within the group.

The degree to which control and management centralization are exerted depends upon the goals of the corporate group in question. Most of them seem intent on displaying excessive coordination of both managerial and operational activities (Romanowska, 2011). This seems to be due to the processes affecting the groups worldwide - the pursuit of internationalization and diversification. 
Although it is hard to find agreement on a universal definition of a corporate group, the one that emphasizes the aspect of legally independent firms with common management prevails (e.g., Colpan \& Hikino, 2010). In other words, a corporate group is a group of inter-related jointly controlled firms, consisting of a parent firm and a number of subsidiaries that can be linked to sub-subsidiaries and other equity associate firms. They are independent entities but they are characterized by coordinated activities through different ties. These ties arise from interactions that are a feature of business networks which, according to Todeva, (2006) encompass not only actors and activities but different resources as well. Thus, a firm fully embedded in the network of corporate group, may hold an advantage over a stand-alone company functioning in the market. This advantage may result from capital availability, know-how and experience sharing, synergy effects, etc. At the same time, it can be argued that control costs, shareholders' individual goals and structural complexity may diminish this predominance.

The concept of a business network is based on the concept of a network in general terms - it is a structure that is formed by nodes tied to each other by particular threads. The nodes in a network are e.g. firms or other organizations and the threads are particular relationships between the actors. Ford, Gadde, Hakansson and Snehota (2011, p.182) stated that the nodes and threads are equipped with tangible and intangible resources. According to Todeva (2006, p. 15) a business network (an industrial network) is a set "of repetitive transactions based on structural and relational formations with dynamic boundaries comprising interconnected elements (actors, resources and activities). Networks accommodate the contradictory and complementary aims pursued by each member, and facilitate joint activities and repetitive exchanges that have specific directionality and flow of information, commodities, heterogeneous resources, individual affection, commitment and trust between the network members". Networks developed by a group of firms often help to promote the operations of each group member and these members can stay financially independent, while at the same time enjoying access to the resources of other members thanks to the inter-firm relationships (Gulati, 1995).

The definition of a network presented by Ford (et al., 2011, p. 182) and in particular the fact that the nodes and threads are equipped with tangible and intangible resources is useful when explaining the possible interdependencies between being a group affiliated firm and being relatively better equipped with resources and capabilities. According to the resource based view (RBV), corporate groups as specific business networks are a type of business organizations that are bundles of idiosyncratic resources and resource conversion activities (Rumelt, 1984). Wernerfelt (1984, p. 172) 
described the resources of a company as anything that can be perceived as a strong or weak side of the organization, and classified them as material resources and assets, which include among others the brand, technological know-how, capabilities, commercial contracts, machines, processes, capital, etc. Corporate group affiliated companies join their strengths and weaknesses within their resources and capabilities. It has been argued by many researchers that interfirm ties contribute to the development and exploitation of competitive resources (e.g., Almeida \& Kogut, 1999; Dyer \& Singh, 1998; Eisenhardt \& Schoonhoven, 1996; Foss \& Eriksen, 1995; Gulati, 1999; Gulati, Nohria \& Zaheer, 2000; Lavie, 2006; McEvily \& Marcus, 2005; Shan \& Kogut, 1994; Sorensen \& Reve, 1998; Uzzi, 1997).

The tangible and intangible resources embedded in the nodes and threads of a network, to some extent, arise from the resources and capabilities of networked firms and simultaneously can increase the sources of competitive advantage of single firms. The interfirm ties provide the corporate group affiliated firms with access to the information, knowledge, resources and markets, and lead to a faster diffusion of knowledge. The pooling of top managerial resources within a corporate group promotes innovation and positively influences the entrepreneurial capacity required per unit of innovative decision-making (Leff, 1978; Belenzon \& Berkovitz, 2010). The set of group-specific assets that can increase the resources and capabilities of group affiliated firms is the corporate group reputation among others (Duysters, Jacob, Lemmens \& Jintianal, 2009). Balcet and Bruschieri (2008) point to the intra-group technology transfer and information flow and the group financial strength that contributes to the group affiliated firm's competitive advantage. Hence, we argue, that:

H1: A corporate group affiliated firm has better resources and capabilities than a non-group affiliated firm.

\section{Corporate group affiliated firms' performance}

New institutional economics constitutes the basic conceptual framework on which research on corporate group performance is based. Particular theories include agency theory and transaction cost approach as well as RBV and institutional theory. However, the different theoretical approaches do not always correspond with one another in regards to corporate group affiliation and firm performance. Based mostly on transaction cost approach and institutional theory researchers found that corporate group affiliation enhances the financial performance since it allows for internalization and hence, transaction costs minimization. It is claimed that, especially in 
the context of developing economies, corporate groups fill in the void of poor-quality legal and regulatory institutions, limited property rights and corruption (Granovetter, 2005) in order to substitute the inefficient market with an efficient internal structure (Estrin, Poukliakova \& Shapiro, 2009). On the other hand, agency theory highlights the multi-layered coordination issues that corporate groups undeniably suffer (Morck, Wolfenzon \& Yeung, 2005) and that in the end may significantly impair the groups' as well as affiliates' effectiveness.

Findings of empirical research are inconclusive with regard to affiliate's performance. Khanna and Rivkin (1999) sampled 13 developing economies to see whether group affiliation has an effect on a firm's financial performance. The results found both evidence for and against the effect. Khanna and Rivkin (1999) applied econometric analysis for financial data of: Argentina, Brazil, Chile, India, Indonesia, Israel, Mexico, Peru, the Philippines, South Korea, Taiwan, Thailand and Turkey. The hypothesis proved to be right for the developed countries and for most of the developing ones (except for Mexico and Peru). Keister (1998) posed a similar question when looking at the transformation process in China. The research focused on the 1980s and proved that corporate group affiliation boosted the member's financial performance. Some scholars (e.g. Bertrand, Mehta \& Mullainathan, 2002; Khanna \& Yafeh, 2005) claim that the positive effect exists although it can happen at the expense of others. In case any affiliated firms face troubles in terms of their performance, other affiliated firms operate under strong pressure to bail them out. The nature of corporate groups manifests itself through sizeable flows of goods among affiliated firms and it can happen that the firms are made to purchase them from other group affiliated firms, irrespective of the quality of the goods. Performance of group affiliated firms may also be affected by different institutional context and overall economic conditions.

In Poland, manufacturing corporate groups generate around PLN 234.3 billion revenue and reach net revenue of around PLN 8.68 billion (CSOP, 2015). Their return on assets is $4.3 \%$ which is 6th place in terms of sectoral breakdown after: mining and quarrying, education, arts, entertainment and recreation, other service and electricity, gas, steam and air conditioning supply. In 2013, the return on investment was around $7.7 \%$ and return on sales $12.3 \%$. Although the overall number of affiliated firms is relatively small, they generate $44 \%$ of the manufacturing gross profit and almost $70 \%$ of the operations revenue. Comparing the gross profit rate for entities affiliated in the corporate groups with the overall manufacturing sector, we can notice that in 2009 and 2010 they achieved about $0.2 \%$ higher rate. Similarly, they performed better in the period 2011-2013 and on average achieved about 
$0.1 \%$ higher rate. Thus, bearing in mind the data of the Central Statistical Office in Poland on the financial performance of manufacturing corporate groups, we will attempt to verify the second hypothesis:

H2: A corporate group affiliated firm has better performance throughout a period of economic crisis and shortly after than the non-group affiliated firm.

A similar hypothesis has been posed in the pre-crisis research of George and Kabir (2012). However, the researchers do not focus on the perception of the resources and capabilities but on the portfolio diversification. They assume that portfolio diversification has a positive effect on a company's resources and capabilities and afterwards prove that group-affiliated firms performed better. Our aim is to verify such dependency in a different geographical and institutional context and to see how the overall economic situation affects the results. By doing so, we seek to observe links among resource and capabilities' perception, group affiliation and performance in Poland.

\section{RESEARCH DESIGN}

\section{Sample and timeframe}

Our empirical research aims to address the question of performance of group affiliated firms against non-group affiliated firms taking into account two restrictions. Firstly, we limit the analysis to one country only, in order to eliminate the distortion caused by institutional differences in each country. Secondly, we restrict the study to manufacturing industries only. We address the question of which firms are more immune to the economic crisis - group affiliates or the non-group affiliates. In doing so, we raise the question of whether the performance-affiliation effect exists and if it depends on the economic situation.

The study is partially based on data from the AMADEUS database and primary data from interviews with top managers of 695 manufacturing firms located in Poland and operating in 7 industries defined according to NACE Rev. 2 at the level of divisions (see Table 1). The sample was determined by a prior analysis with the use of linear ordering of objects and the results of this analysis are broadly presented in another paper (e.g., Dzikowska, Gorynia \& Jankowska, 2015). It is useful to underline that the aim of the delimitation was to identify industries in which firms did relatively well during the economic crisis (division 10, 17, 25, 32) in Poland and those that 
had difficulties with returning to pre-crisis performance (division 14, 15, 24). Subsequently, a ranking of industries was developed. The industries included in our study encompass $44 \%$ of firms registered in Poland and operating in the manufacturing sector.

First, the authors used the data presented in the Amadeus database. Only firms with complete contact and financial records were taken into consideration. It turned out that in this proprietary electronic database there are 2533 firms with complete records representing the 7 selected industries ${ }^{5}$. Then, thereof, 750 firms were randomly contacted in July and August 2015 resulting in an effective response rate of 93\%. In the study we wanted to investigate the implications of corporate group affiliation, during the crisis period and shortly after, for the sources of competitive advantage and performance of group affiliated firms. Thus we took into consideration only those entities that, within the whole period of time, were members of the same type of corporate group. In our study we distinguished between a Polish and an international corporate group. We contrasted the data for these entities with the data for firms that, within the whole period of time, stayed out of any corporate group. Since few companies migrated between the two distinguished types of corporate groups, we eventually had 695 entities included in the research sample.

Among those 695 companies, there are 43 micro, 220 small, 284 medium entities and 148 large entities. To characterize the size of the firms we used the number of employees in the crisis year 2009. The majority of corporate group affiliated firms represent division 10 (319 entities) and division 25 (226 entities) which are industries that coped relatively well with the crisis. 317 firms were not affiliated within any corporate group, 202 firms had affiliation within a Polish corporate group and 176 operated within an international corporate group.

The timeframe for the study embraces the period 2009-2013. The timeframe of five years was intentionally assumed. The first symptoms of the global economic crisis in Poland were visible in the second half of 2008; hence the year 2009 was defined as the period of the crisis. The growth of GDP in 2009 was $2.3 \%$, down from 5.13\% in 2008. In 2010, GDP growth recovered to the level of 3.88\% (World Development Indicators, 2015). We assume that after 2009 we have the so called post-crisis period when the positive and negative consequences of the economic crisis emerged.

5 That is the number of entities in the database without records related to firms that participated in the pilot study that was conducted by the authors in 2014 . 
Table 1. Sectoral structure of the sample - number of firms from particular divisions and their involvement in corporate groups [ $\mathrm{N}=695$ ]

\begin{tabular}{|c|c|c|c|c|c|}
\hline Division & Description of activity & FNG & FPG & FIG & $\begin{array}{l}\text { Total } \\
\text { number }\end{array}$ \\
\hline Division 10 & manufacture of food products & 159 & 92 & 68 & 319 \\
\hline Division 25 & $\begin{array}{l}\text { manufacture of fabricated metal } \\
\text { products, except machinery and } \\
\text { equipment }\end{array}$ & 90 & 72 & 64 & 226 \\
\hline Division 17 & $\begin{array}{l}\text { manufacture of paper and paper } \\
\text { products }\end{array}$ & 25 & 9 & 23 & 57 \\
\hline Division 24 & manufacture of basic metals & 15 & 13 & 5 & 33 \\
\hline Division 32 & $\begin{array}{l}\text { manufacture of other } \\
\text { manufacturing }\end{array}$ & 12 & 7 & 7 & 26 \\
\hline Division 14 & manufacture of wearing apparel & 12 & 5 & 8 & 25 \\
\hline Division 15 & $\begin{array}{l}\text { manufacture of leather and related } \\
\text { products }\end{array}$ & 4 & 4 & 1 & 9 \\
\hline
\end{tabular}

FNG - non-group affiliated firm, FPG - a Polish group-affiliated firm, FIG - an international group-affiliated firm.

\section{Methods, variables and operationalization}

Firstly, we divided the whole sample into three groups of distinctive entities: (1) not operating in any corporate group (FNG), (2) firms participating in Polish corporate groups (FPG) and (3) entities performing within international corporate groups (FIG). The division was necessary to verify the interdependencies between group affiliation and sources of competitive advantage and to identify the potential implications for the firm's performance at the time of the economic crisis and in the post crisis period. For the purpose of our study we defined the Polish corporate group as a group where the parent company was located in Poland and an international group as a group where the parent company is of foreign origin.

The variables used in the study are described in Table 2. We looked for possible differences in the firm's perception of sources of competitive advantage. To characterize the construct - the sources of competitive advantage within the three defined groups of entities - we used variables explained in Table 2. Using Cronbach's alfa we checked if the broad set of variables measures the construct of the source of competitive advantage in a reliable way. Last, but not least, we conducted the Kruskal-Wallis non-parametric analysis of variance for the variables of resources and capabilities. To evaluate the firm's performance we used two types of variables - objective and subjective ones. To check if the set of variables was internally consistent, reliable and all variables measure the same construct, we calculated Cronbach's alfa (see Table 2). Then, we tried to verify if there are any statistically significant differences among the firms operating outside 
corporate groups (FNG) and operating within corporate groups, with the distinction between Polish (FPG) and international corporate groups (FIG). For that purpose we used Kruskal-Wallis non-parametric analysis of variance since, to evaluate the variables, we used the ordinal scale and there were more than three different groups of entities (FNG, FPG and FIG).

Table 2. Operationalisation of variables

\begin{tabular}{|c|c|c|}
\hline Variable & Operationalisation & $\begin{array}{l}\text { Internal } \\
\text { consistency }\end{array}$ \\
\hline $\begin{array}{l}\text { Sources of } \\
\text { competitive } \\
\text { advantage in the } \\
\text { crisis period (2009) }\end{array}$ & $\begin{array}{l}13 \text { indicators on a 7-point Likert scale, where "-3" } \\
\text { stands for "much worse than direct competitors", and } \\
\text { "3" stands for "much better than direct competitors". } \\
\text { The set of indicators included resources and } \\
\text { capabilities. }\end{array}$ & \\
\hline Resources & $\begin{array}{l}\text { Material resources, human resources, intangible } \\
\text { resources (knowledge, brand, patents, etc.), financial } \\
\text { resources. }\end{array}$ & \\
\hline Capabilities & $\begin{array}{l}\text { Logistics (performance and efficiency), production } \\
\text { (performance and efficiency), marketing and sales } \\
\text { (effectiveness and efficiency), service (effectiveness } \\
\text { and efficiency), supplies (performance and } \\
\text { efficiency), technology (advancement and efficiency), } \\
\text { management of human resources (efficiency and } \\
\text { performance), firm management systems (efficiency } \\
\text { and effectiveness), quality control (efficiency) }\end{array}$ & $\begin{array}{l}\text { Cronbach's } \\
\text { Alpha } \\
(2009)=0.979\end{array}$ \\
\hline
\end{tabular}

Performance in the crisis (2009) and post-crisis period(2011-the time of prosperity, 2013)

\begin{tabular}{lll}
\hline Subjective measures & 5 variables (profitability, sales growth, market share, & Cronbach's \\
& overall financial condition, customer satisfaction) & Alpha $(2009)=$ \\
& evaluated with the use of 7-point Likert scale, where & $0.958,(2011)=$ \\
& "-3" stands for "much worse than direct competitors", $0.947(2013)=$ \\
& "3" stands for "much better than direct competitors" & 0.948 \\
Objective measures & 4 variables related to the financial position of a firm: \\
& $\begin{array}{l}\text { the profit margin (EBIT/revenues), sales growth } \\
\text { (based on company revenues - year to year), return } \\
\text { on equity }\end{array}$
\end{tabular}

Common method bias is possible as our data are to a large extent based on perceptual measures from single respondents of each firm. To decrease the risk of common method bias that could artificially inflate the observed relationships between variables (Campbell and Fiske, 1959), respondents were not aware of the hypothesised relationships shown in the study. Additionally, we included data, such as profit margin (EBIT/revenues), sales growth (based on company revenues year to year) and return on equity, based on secondary information from AMADEUS. 


\section{ANALYSIS AND RESULTS}

\section{Sources of competitive advantage in the period of the economic crisis -corporate group affiliates against the non-group firms}

We tried to investigate whether the enhanced resources and capabilities of firms operating within the corporate groups, as detailed in the literature, could explain their better performance in the crisis and post-crisis periods. At first we analyzed the sources of competitive advantage of the firms representing the three distinct groups in 2009. Then we verified whether some additional company characteristics (e.g. company size) affected the study. As no evidence was found, we have included these characteristics in the research. A closer look at the resources and capabilities of FNG, FPG and FIG allows us to state that the highest mean values were reported among FIG (Table 4). Firms affiliated within international corporate groups perceived their resources and capabilities in the crisis year 2009 better than the affiliates of Polish corporate groups and the rest of the entities. In order to verify whether the differences in the resources and capabilities of FNG, FPG and FIG are statistically significant, we used the non-parametric analysis of variance. The results presented in Table 3 include critical values and significance levels in relation to the sources of competitive advantage, where clear differences were observed in the distribution of the answers related to the evaluation of its particular elements. The obtained significance levels ( $p$-values) for the differences in resources and capabilities of firms from the three defined types of corporate groups were lower than 0.05 , thus they are statistically significant. It justifies the hypothesis that firms operating within corporate groups are better equipped to cope with unfavourable external circumstances.

\section{Performance in the period of the economic crisis and shortly after - corporate group affiliates against the non-group affiliates}

Performance of the firms was evaluated with the use of two types of variables; objective measures based on financial data retrieved from the electronic Amadeus database - profit margin (EBIT/revenues), sales growth (based on company revenues - year to year), return on equity) and; subjective measures which present the perception of profitability, sales growth, market share, overall financial condition, and customer satisfaction [as perceived by the managers who represented these companies] (see Table 2). Analysing the descriptive statistics for the objective measure we notice that the highest mean values in the crisis year 2009 are characteristic of FPG with one exception - return on equity is highest for FIG and FNG (Table 3). 
Table 3. Resources and capabilities in 2009 - perspective of FNG, FPG, FIG descriptive statistics and non-parametric analysis of variance

\begin{tabular}{|c|c|c|c|c|c|}
\hline $\begin{array}{l}\text { Sources of competitive } \\
\text { advantage }\end{array}$ & $\begin{array}{l}\text { Type of } \\
\text { corporate } \\
\text { group if } \\
\text { any }\end{array}$ & MEAN $^{\mathrm{a}}$ & $\mathbf{S D}^{\mathrm{a}}$ & $\begin{array}{l}\text { Kruskal- } \\
\text { Wallis test }\end{array}$ & $\begin{array}{l}\text { Level of } \\
\text { significance }\end{array}$ \\
\hline \multirow{4}{*}{$\begin{array}{l}\text { Material resources } \\
\text { (available machines. Assets } \\
\text { and infrastructure) }\end{array}$} & FNG & 0.45 & 0.92 & & \\
\hline & FPG & 0.54 & 1.00 & $\mathrm{H}=43.277$ & $p=0.000$ \\
\hline & FIG & 1.13 & 1.17 & & \\
\hline & FNG & 0.49 & 0.82 & $\mathrm{H}=47.7891$ & $p=0.000$ \\
\hline \multirow[t]{2}{*}{ Human resources } & FPG & 0.58 & 0.94 & & \\
\hline & FIG & 1.16 & 1.12 & & \\
\hline \multirow{4}{*}{$\begin{array}{l}\text { Intangible resources } \\
\text { (knowledge. brand. patents. } \\
\text { etc.) }\end{array}$} & FNG & 0.50 & 0.90 & $\mathrm{H}=44.352$ & $p=0.000$ \\
\hline & FPG & 0.54 & 1.00 & & \\
\hline & FIG & 1.16 & 1.14 & & \\
\hline & FNG & 0.40 & 0.96 & $\mathrm{H}=44.903$ & $p=0.000$ \\
\hline \multirow[t]{2}{*}{ Financial Resources } & FPG & 0.49 & 1.06 & & \\
\hline & FIG & 1.13 & 1.17 & & \\
\hline \multirow{3}{*}{$\begin{array}{l}\text { Logistics (efficiency and } \\
\text { effectiveness) }\end{array}$} & FNG & 0.49 & 0.76 & $H=61.519$ & $p=0.000$ \\
\hline & FPG & 0.59 & 0.91 & & \\
\hline & FIG & 1.18 & 1.03 & & \\
\hline \multirow{3}{*}{$\begin{array}{l}\text { Production (efficiency and } \\
\text { effectiveness) }\end{array}$} & FNG & 0.79 & 0.95 & $H=25.758$ & $p=0.000$ \\
\hline & FPG & 0.79 & 1.05 & & \\
\hline & FIG & 1.26 & 1.29 & & \\
\hline \multirow{4}{*}{$\begin{array}{l}\text { Marketing and } \\
\text { sales(effectiveness and } \\
\text { efficiency) }\end{array}$} & FNG & 0.47 & 1.23 & $\mathrm{H}=25.025$ & $p=0.000$ \\
\hline & FPG & 0.50 & 1.38 & & \\
\hline & FIG & 1.04 & 1.67 & & \\
\hline & FNG & 0.32 & 1.10 & $\mathrm{H}=24.022$ & $p=0.000$ \\
\hline \multirow{2}{*}{$\begin{array}{l}\text { Service (efficiency and } \\
\text { effectiveness) }\end{array}$} & FPG & 0.32 & 1.29 & & \\
\hline & FIG & 0.92 & 1.59 & & \\
\hline \multirow{3}{*}{$\begin{array}{l}\text { Supply (efficiency and } \\
\text { effectiveness) }\end{array}$} & FNG & 0.80 & 0.93 & $H=25.984$ & $p=0.000$ \\
\hline & FPG & 0.77 & 1.03 & & \\
\hline & FIG & 1.25 & 1.29 & & \\
\hline \multirow{3}{*}{$\begin{array}{l}\text { Technology (advancement and } \\
\text { performance) }\end{array}$} & FNG & 0.45 & 0.91 & $\mathrm{H}=43.194$ & $p=0.000$ \\
\hline & FPG & 0.53 & 1.02 & & \\
\hline & FIG & 1.14 & 1.16 & & \\
\hline \multirow{3}{*}{$\begin{array}{l}\text { HR management (efficiency } \\
\text { and effectiveness) }\end{array}$} & FNG & 0.49 & 0.82 & $H=55.732$ & $p=0.000$ \\
\hline & FPG & 0.60 & 0.96 & & \\
\hline & FIG & 1.22 & 1.13 & & \\
\hline \multirow{4}{*}{$\begin{array}{l}\text { Company management } \\
\text { systems(efficiency and } \\
\text { effectiveness) }\end{array}$} & FNG & 0.50 & 1.21 & $H=24.362$ & $p=0.000$ \\
\hline & FPG & 0.48 & 1.35 & & \\
\hline & FIG & 1.03 & 1.66 & & \\
\hline & FNG & 0.32 & 1.09 & $H=21.079$ & $p=0.000$ \\
\hline \multirow[t]{2}{*}{ Quality control (efficiency) } & FPG & 0.29 & 1.25 & & \\
\hline & FIG & 0.87 & 1.60 & & \\
\hline
\end{tabular}

${ }^{a}$ Mean and SD of resources and competences. 
In 2011, a period associated with economic prosperity in Poland, the top position belonged to FIG, despite sales growth being better in the case of FPG. Two years later in 2013, the sales growth of firms was the highest in the case of FIG, but profit margin and return on equity was better for FPG. The evaluation of performance with the use of these measures didn't provide a conclusive picture.

Table 4. Objective performance indicators in 2009, 2011 and 2013 - perspective of FNG, FPG, FIG - descriptive statistics

\begin{tabular}{llrrrrrr}
\hline $\begin{array}{l}\text { Objective } \\
\text { performance } \\
\text { indicators }\end{array}$ & $\begin{array}{l}\text { Type of } \\
\text { corporate }\end{array}$ & \multicolumn{2}{c}{2009} & \multicolumn{2}{c}{2011} & \multicolumn{2}{c}{2013} \\
\cline { 2 - 8 } & group if any & MEAN & SD & MEAN & SD & MEAN & \multicolumn{1}{c}{ SD } \\
\hline \multirow{3}{*}{ Sales growth } & FNG & 0.83 & 11.03 & 0.14 & 0.28 & -0.01 & 0.24 \\
& FPG & 2.31 & 27.79 & 0.75 & 7.50 & 0.05 & 0.69 \\
& FIG & 0.81 & 8.01 & 0.22 & 0.33 & 0.06 & 0.23 \\
Profit margin & FNG & -0.01 & 0.74 & -0.20 & 3.37 & -0.07 & 2.20 \\
& FPG & 0.09 & 1.18 & 0.00 & 0.23 & 0.11 & 1.20 \\
& FIG & 0.04 & 0.11 & 0.05 & 0.08 & 0.03 & 0.31 \\
Return on equity & FNG & 0.16 & 0.80 & 0.10 & 1.04 & -0.53 & 11.79 \\
& FPG & 0.15 & 1.08 & 0.06 & 0.81 & 0.27 & 1.93 \\
& FIG & 0.16 & 1.39 & 0.13 & 1.21 & 0.21 & 0.37 \\
\hline
\end{tabular}

The subjective measures bring a more clear and unambiguous picture. FIGs perceived their performance as better than FNG and FPG in 2009 and in the post-crisis time in Poland (Table 5). FNG evaluated the subjective measures of performance as better in the crisis year than FPG with one exception - client satisfaction. The post-crisis time brought the relatively best position of FIG and then FPG. However, bearing in mind the scale used to evaluate the performance (see Table 2) we have to state that the evaluation is quite low since the mean values for resources and capabilities in 2011 and 2013 oscillate between 0.45 and 1.42. However, the worst results are a characteristic of the time of the economic crisis, and reveal an awareness within the firms that they did not operate very well in this period but that they were better than their competitors. Looking at the performance measures of FIG and FPG against the FNG we can notice that the first two types of entities reported better results which can be associated with their resistance to the unfavourable external conditions. 
Table 5. Subjective performance indicators in 2009, 2011 and 2013 - perspective of FNG, FPG, FIG - descriptive statistics

\begin{tabular}{|c|c|c|c|c|c|c|c|}
\hline \multirow{2}{*}{$\begin{array}{l}\text { Subjective } \\
\text { performance } \\
\text { indicators }\end{array}$} & \multirow{2}{*}{$\begin{array}{l}\text { Type of } \\
\text { corporate } \\
\text { group if any }\end{array}$} & \multicolumn{2}{|c|}{2009} & \multicolumn{2}{|c|}{2011} & \multicolumn{2}{|c|}{2013} \\
\hline & & MEAN & SD & MEAN & SD & MEAN & SD \\
\hline \multirow{3}{*}{ Profitability } & FNG & 0.50 & 1.34 & 0.45 & 1.24 & 0.71 & 1.35 \\
\hline & FPG & 0.38 & 1.48 & 0.53 & 1.40 & 0.69 & 1.54 \\
\hline & FIG & 0.86 & 1.74 & 1.10 & 1.67 & 1.38 & 1.50 \\
\hline \multirow{3}{*}{ Sales growth } & FNG & 0.62 & 1.37 & 0.51 & 1.28 & 0.72 & 1.34 \\
\hline & FPG & 0.51 & 1.49 & 0.54 & 1.38 & 0.73 & 1.52 \\
\hline & FIG & 0.98 & 1.73 & 1.10 & 1.69 & 1.39 & 1.51 \\
\hline \multirow{3}{*}{ Market share } & FNG & 0.51 & 1.32 & 0.48 & 1.28 & 0.69 & 1.35 \\
\hline & FPG & 0.41 & 1.49 & 0.53 & 1.40 & 0.71 & 1.56 \\
\hline & FIG & 0.89 & 1.66 & 1.09 & 1.69 & 1.39 & 1.50 \\
\hline \multirow{3}{*}{$\begin{array}{l}\text { Overall financial } \\
\text { condition }\end{array}$} & FNG & 0.61 & 1.42 & 0.60 & 1.35 & 0.68 & 1.39 \\
\hline & FPG & 0.53 & 1.48 & 0.67 & 1.41 & 0.69 & 1.55 \\
\hline & FIG & 1.03 & 1.69 & 1.29 & 1.61 & 1.37 & 1.59 \\
\hline \multirow{3}{*}{ Client satisfaction } & FNG & 0.78 & 0.79 & 0.80 & 0.77 & 0.81 & 0.77 \\
\hline & FPG & 0.90 & 0.88 & 0.92 & 0.87 & 0.92 & 0.87 \\
\hline & FIG & 1.41 & 1.04 & 1.41 & 1.04 & 1.42 & 1.04 \\
\hline
\end{tabular}

In order to check whether the differences in the performance of FNG, FPG and FIG, evaluated with the subjective measures, are statistically significant we used the Kruskal-Wallis test. The results are presented in Table 6. The obtained significance levels ( $p$-values) for the differences in the performance of firms not involved in any corporate group and firms involved in Polish or international corporate groups are below 0.05 and thus are statistically significant. It justifies the hypothesis that firms operating within corporate groups were able to cope better with unfavourable external circumstances.

Table 6. Subjective performance indicators in 2009, 2011 and 2013 - perspective of FNG, FPG, FIG - non-parametric analysis of variance

\begin{tabular}{|c|c|c|c|c|c|c|}
\hline \multirow{2}{*}{$\begin{array}{l}\text { Subjective } \\
\text { performance } \\
\text { indicators }\end{array}$} & \multicolumn{2}{|c|}{2009} & \multicolumn{2}{|c|}{2011} & \multicolumn{2}{|c|}{2013} \\
\hline & $\begin{array}{l}\text { Kruskal- } \\
\text { Wallis test }\end{array}$ & $\begin{array}{l}\text { Level of } \\
\text { significance }\end{array}$ & $\begin{array}{l}\text { Kruskal- } \\
\text { Wallis test }\end{array}$ & $\begin{array}{l}\text { Level of } \\
\text { significance }\end{array}$ & $\begin{array}{l}\text { Kruskal- } \\
\text { Wallis test }\end{array}$ & $\begin{array}{l}\text { Level of } \\
\text { significance }\end{array}$ \\
\hline Profitability & $H=15.385$ & $p=0.001$ & $H=30.45400$ & $p=0.000$ & $\mathrm{H}=30.309$ & $p=0.000$ \\
\hline Sales growth & $H=14.009$ & $p=0.001$ & $\mathrm{H}=25.833$ & $p=0.000$ & $\mathrm{H}=30.862$ & $p=0.000$ \\
\hline $\begin{array}{l}\text { Mark } \\
\text { share }\end{array}$ & $\mathrm{H}=14.697$ & $p=0.001$ & $\mathrm{H}=27.141$ & $p=0.000$ & $\mathrm{H}=31.758$ & 000 \\
\hline $\begin{array}{l}\text { Overall finan- } \\
\text { cial condition }\end{array}$ & $H=16.476$ & $p=$ & 298 & .000 & .515 & $p=0.000$ \\
\hline $\begin{array}{l}\text { Client satis- } \\
\text { faction }\end{array}$ & $\mathrm{H}=45.6326$ & $p=0.000$ & $\mathrm{H}=43.57174$ & $p=0.000$ & $\mathrm{H}=42.685$ & $=0.000$ \\
\hline
\end{tabular}


In hypothesis 2 we indicated that the corporate group affiliated firms enjoyed better performance than the non-affiliated firms during the economic crisis and shortly after. The hypothesized explanation for that could be resources and capabilities that form the sources of competitive advantage. To check the potential interdependencies between the sources of competitive advantage and the performance of firms, in the crisis time and shortly after, we calculated the Spearman's rank correlation coefficient for the indicators of the sources of competitive advantage and performance indicators. The results are presented in table 7,8 and 9 . The highest correlation coefficients for sources of competitive advantage and all performance indicators considered for FPGs, FNGs and FIGs were in 2009. The value dropped in the years 2011 and 2013 but was still significant at the level of above 0.4. The strongest correlation between the sources of competitive advantage and performance measures in the crisis year 2009 was characteristic for FIGs, the second position belonged to FNGs.

Table 7. Correlation coefficients for indicators of the sources of competitive advantage in the crisis time and performance measures - perspective of FPG

\begin{tabular}{|c|c|c|c|c|c|c|c|c|c|c|c|c|c|c|}
\hline & & RS1 & RS2 & RS3 & RS4 & RS5 & RS6 & RS7 & RS8 & RS9 & RS10 & RS11 & RS12 & RS13 \\
\hline \multirow{5}{*}{ 옹 } & P1 & 0.657 & 0.588 & 0.618 & 0.672 & 0.673 & 0.767 & 0.831 & 0.865 & 0.764 & 0.652 & 0.574 & 0.839 & 0.801 \\
\hline & P2 & 0.673 & 0.597 & 0.653 & 0.683 & 0.704 & 0.782 & 0.893 & 0.892 & 0.780 & 0.674 & 0.596 & 0.904 & 0.859 \\
\hline & P3 & 0.692 & 0.600 & 0.647 & 0.692 & 0.684 & 0.765 & 0.857 & 0.885 & 0.760 & 0.697 & 0.608 & 0.866 & 0.832 \\
\hline & P4 & 0.642 & 0.598 & 0.643 & 0.681 & 0.680 & 0.759 & 0.899 & 0.881 & 0.765 & 0.648 & 0.601 & 0.914 & 0.840 \\
\hline & P5 & 0.680 & 0.651 & 0.607 & 0.618 & 0.665 & 0.548 & 0.622 & 0.634 & 0.540 & 0.676 & 0.648 & 0.613 & 0.620 \\
\hline \multirow{5}{*}{ ¿্ं } & P1 & 0.508 & 0.504 & 0.527 & 0.514 & 0.584 & 0.408 & 0.575 & 0.555 & 0.436 & 0.519 & 0.546 & 0.593 & 0.665 \\
\hline & P2 & 0.527 & 0.522 & 0.528 & 0.525 & 0.591 & 0.465 & 0.622 & 0.602 & 0.479 & 0.536 & 0.564 & 0.632 & 0.705 \\
\hline & P3 & 0.538 & 0.531 & 0.533 & 0.539 & 0.599 & 0.476 & 0.624 & 0.600 & 0.498 & 0.546 & 0.573 & 0.631 & 0.705 \\
\hline & P4 & 0.548 & 0.549 & 0.582 & 0.583 & 0.657 & 0.520 & 0.698 & 0.685 & 0.544 & 0.557 & 0.574 & 0.714 & 0.756 \\
\hline & P5 & 0.689 & 0.638 & 0.614 & 0.609 & 0.676 & 0.552 & 0.626 & 0.639 & 0.537 & 0.674 & 0.634 & 0.612 & 0.625 \\
\hline \multirow{5}{*}{$\stackrel{m}{\stackrel{n}{\sim}}$} & P1 & 0.481 & 0.443 & 0.492 & 0.497 & 0.621 & 0.466 & 0.650 & 0.611 & 0.482 & 0.493 & 0.465 & 0.669 & 0.660 \\
\hline & P2 & 0.487 & 0.447 & 0.473 & 0.497 & 0.651 & 0.482 & 0.674 & 0.632 & 0.483 & 0.489 & 0.484 & 0.680 & 0.676 \\
\hline & P3 & 0.503 & 0.460 & 0.492 & 0.509 & 0.652 & 0.492 & 0.674 & 0.632 & 0.503 & 0.514 & 0.502 & 0.685 & 0.685 \\
\hline & P4 & 0.483 & 0.447 & 0.497 & 0.517 & 0.606 & 0.457 & 0.650 & 0.620 & 0.466 & 0.487 & 0.465 & 0.663 & 0.657 \\
\hline & P5 & 0.696 & 0.624 & 0.613 & 0.613 & 0.677 & 0.548 & 0.629 & 0.640 & 0.527 & 0.679 & 0.632 & 0.612 & 0.626 \\
\hline
\end{tabular}

RS1 - material resources, RS2 - human resources, RS3 - intangible resources (knowledge, brand, patents, etc.); RS4 - financial resources; RS5 - Logistics (performance and efficiency), RS6 - production (performance and efficiency), RS7 - marketing and sales (effectiveness and efficiency), RS8 - service (effectiveness and efficiency), RS9 - supplies (performance and efficiency), RS10 - technology(advancement and efficiency), RS11 - management of human resources (efficiency and performance), RS 12 - firm management systems (efficiency and effectiveness), RS13 - quality control (efficiency). P1 - profitability, P2 - sales growth, P3 market share, P4 - overall financial condition, P5 - customer satisfaction. 
Correlation coefficients in 2009 were relatively the lowest for FPG, which could indicate that in the crisis time the impact of internal factors on the performance of the Polish group affiliates may have been weakened because of unfavourable external conditions. FPGs are groups where the parent company is headquartered in Poland which means that the transmission of negative changes in the Polish economy in 2009 happened via the interactions among the siblings affiliated in the group and located in Poland and interactions between the parent company headquartered in Poland and other group affiliated firms. As far as FIGs are concerned the interactions affected by the situation in the Polish market took place just among the group affiliates operating in the Polish market. The transmission of external shocks, a characteristic of the Polish market in 2009, was possible via the interactions among group affiliates located in this market and not via the relations with the parent company operating in a different national market. The interactions with the international parent company in that year could have been the remedy against the negative impact of interactions among Polish-based affiliates. The correlation coefficients presented in tables 7, 8, 9 are statistically significant with $p<0.05$.

Table 8. Correlation coefficients for indicators of the sources of competitive advantage in the crisis time and performance measures - perspective of FIG

\begin{tabular}{|c|c|c|c|c|c|c|c|c|c|c|c|c|c|c|}
\hline & & RS1 & S2 & RS3 & RS4 & RS5 & RS6 & RS7 & RS8 & RS9 & RS10 & RS11 & RS12 & RS13 \\
\hline \multirow{5}{*}{ ర్సి } & . & 7 & 8 & 1 & 1 & 4 & 9 & 54 & 389 & 1 & 20 & 70 & 358 & 0.834 \\
\hline & 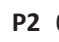 & 0 & 7 & 67 & 72 & 2 & 0.842 & 8 & 910 & 4 & 771 & 31 & 13 & 0.885 \\
\hline & 3 & 0.824 & 801 & 0.820 & 0.825 & 0.803 & 0.814 & 0.877 & 0.905 & 0.816 & 0.829 & 0.783 & 0.881 & 0.865 \\
\hline & P4 & 0 & 0.744 & 56 & 0.770 & 8 & 2 & 29 & 0.915 & 0.865 & 70 & 725 & 0.925 & 0.908 \\
\hline & P5 & 0.878 & 0.848 & 0.881 & 0.866 & 0.858 & 0.781 & 0.856 & 0.877 & 0.778 & 876 & .837 & 853 & 0.844 \\
\hline \multirow{5}{*}{ ర్ల } & P1 & 0556 & 0546 & 582 & $L$ & $B$ & 0.613 & 0.662 & 0 & 5 & 18 & 55 & 0.666 & 0.768 \\
\hline & P2 & 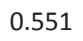 & . & & , & 8 & 0. & 0.072 & 5 & 9 & & & & \\
\hline & 33 & 0.550 & 0.541 & 0.576 & 0.553 & 0.646 & 0.628 & 0.677 & 0.699 & 0.626 & 0.550 & 0.564 & 0.678 & 0.774 \\
\hline & P4 & 0 & 0.582 & 0.606 & 0.587 & 0 & 0 & 0696 & 0.711 & 1 & 82 & 0.589 & 0.699 & 0.775 \\
\hline & P5 & 0 & 0.848 & & $c$ & & & & & & & & & 0.844 \\
\hline \multirow{5}{*}{ - } & P1 & 479 & 0.486 & 0.479 & 0.483 & 0.676 & 0.5 & 0.555 & 0.566 & 0.539 & 0.478 & 0.475 & 0.562 & 0. \\
\hline & P2 & 0.468 & 0.47 & 0.473 & 0.459 & 3 & 0.5 & 0.536 & 0.552 & 0.5 & 58 & 55 & 6 & 0.557 \\
\hline & P3 & 0.476 & 0.483 & 0.480 & 0.478 & 0.673 & 0.532 & 552 & 0.566 & 0.532 & 0.476 & 0.469 & 0.557 & 0.572 \\
\hline & P4 & 0.4 & 0.4 & 0.474 & 0. & 0.665 & 0.530 & 0. & 0.556 & 0.5 & 0.478 & 0.474 & 0.5 & 0.568 \\
\hline & P5 & 0.865 & 0.847 & 2 & & & 0 & & b & 9 & & 0.827 & 0.845 & 0. \\
\hline
\end{tabular}


Table 9. Correlation coefficients for indicators of the sources of competitive advantage in the crisis time and performance measures - perspective of FNG

\begin{tabular}{|c|c|c|c|c|c|c|c|c|c|c|c|c|c|c|}
\hline & & RS1 & RS2 & RS3 & RS4 & RS5 & RS6 & RS7 & RS8 & RS9 & RS10 & RS11 & RS12 & RS13 \\
\hline \multirow{5}{*}{ 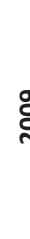 } & P1 & 702 & 0.635 & 684 & 0.761 & 0.654 & 612 & 0.812 & 0.808 & 0.609 & 0.718 & 0.639 & 780 & 0.1 \\
\hline & P2 & 680 & 609 & 680 & 0.712 & 684 & 670 & 0.858 & 0.835 & 0.663 & 0.688 & 0.606 & 0.836 & 0.813 \\
\hline & P3 & 0.687 & 0.674 & 0.698 & 0.706 & 0.696 & 0.610 & 0.812 & 0.823 & 0.626 & 0.714 & 0.663 & 0.800 & 0.782 \\
\hline & P4 & 0.666 & 0.632 & 656 & 0.704 & 0.692 & 0.676 & 0.886 & 847 & 670 & 0.680 & 0.614 & .867 & 0.828 \\
\hline & P5 & 0.638 & 0.650 & 0.669 & 0.638 & 0.652 & 0.418 & 0.639 & 0.660 & 0.427 & 0.692 & 0.626 & 650 & 0.65 \\
\hline & P1 & 0.459 & 0.425 & 5 & 0.495 & 0.557 & 9 & 0.675 & 29 & 14 & 77 & 16 & 652 & 68 \\
\hline & P2 & 0.516 & 400 & 535 & . & כ & 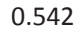 & ו & 0.702 & 0.541 & IJ.נ. & 0.472 & 0.722 & 0.1. \\
\hline & P3 & 0.503 & 0.501 & 0.528 & 0.509 & 0.625 & 0.524 & 0.729 & 0.699 & 0.533 & 0.524 & 0.480 & 0.728 & 0.741 \\
\hline & P4 & 0.520 & 500 & .524 & 0.53 & 0.6 & 0.544 & 07 & 0.724 & 0.550 & 0.5 & 0.474 & 40 & c \\
\hline & P5 & 615 & 0.646 & 663 & 0.6 & 0 & 0.393 & 0. & 0.658 & 0.405 & & & 50 & 0.662 \\
\hline \multirow{5}{*}{ סं } & P1 & 0.477 & 0.450 & 487 & 0.462 & 0.638 & 0.49 & 0.62 & 0.627 & 0.485 & 0.47 & 0.4 & 0.637 & 0. \\
\hline & P2 & 0.484 & 0 & 0.478 & 0.470 & 0.640 & 0.491 & 0.6 & 0.634 & 0.490 & 0.468 & 0.434 & 0.639 & 0.637 \\
\hline & P3 & 0.456 & 0.445 & 0.473 & 0.459 & 0.627 & 0.474 & 0.633 & 0.621 & 0.494 & 0.463 & 0.439 & 0.640 & 0.634 \\
\hline & P4 & 0.485 & 0.459 & 0.481 & 0.443 & 0.641 & 0.479 & 0.632 & 0.657 & 0.494 & 0.474 & 0.441 & 0.652 & 0.655 \\
\hline & P5 & 625 & 4 & 653 & 0.617 & 0.645 & 0.389 & 0.621 & 0.649 & 0.391 & $0 \Leftrightarrow$ & 6 & 38 & 0 \\
\hline
\end{tabular}

\section{CONCLUSION, LIMITATIONS AND IMPLICATIONS FOR FURTHER STUDIES}

Our research corroborates the findings of previous studies on the impact of group affiliation on the sources of competitive advantage and performance of firms. Based on the methodology presented before, first we show that the group affiliated entities enjoy better resources and capabilities against the non-group affiliated firms and second, thanks to being better equipped they can achieve better performance even in the crisis time and shortly after. The results of the analysis, with the use of descriptive statistics, clearly demonstrate that corporate groups can be regarded as bundles of particular resources and firms within these groups can take advantage of the resources and capabilities embedded in the inter-firm ties. The statistically significant differences within the sources of competitive advantage among the firms affiliated in the Polish groups, international corporate groups, and stand-alone firms prove that the affiliation matters for the sources of competitive advantage not only in times of prosperity but during a period of economic crisis.

Our descriptive findings reflect the assumption that the crisis time affects the firms since the assessment of resources and capabilities was rather low when we take into account the scale used in the survey. But looking for the highest ranks we can easily notice that the best "scores" go to the firms affiliated 
within international corporate groups. This result can be on one hand surprising and on the other hand not. Bearing in mind the fact that the economic crisis was first noticeable in 2008, not in Poland but in other countries that, in many cases, were the location of headquarters of parent firms in international groups, the result is surprising. However, contradictory reasoning can be that the pool of resources and capabilities in the case of international group affiliated firms was greater shortly before the crisis, which is why even in 2009 their sources of competitive advantage were better evaluated.

Better resources and capabilities, which are characteristic of Polish and especially international group affiliated entities against stand-alone firms, translate into better assessment of performance measures of firms involved in both types of corporate groups. In this context we can state that both hypotheses were confirmed. And in particular, FIG's greater resilience to the crisis, which is proved by their relatively better performance, can be explained by their access to external and intra-group resources and capabilities. It may have given these firms the support needed for their relatively higher profitability, sales growth, market share, overall financial situation and perceived client satisfaction. All in all, our findings suggest that Polish firms affiliated in international corporate groups were more resilient to the economic crisis despite the commonly accepted thesis that international corporate groups may have acted as synchronization factors among crisis phenomena across different national markets.

The study provides some practical implications related to the justification for the existence of corporate groups in general and during the period of economic crisis in particular. The international group affiliated firms excel in all dimensions of their performance in the crisis and in the post-crisis period. The Polish group affiliated firms faced the worst performance (subjective measures) in the crisis period 2009 compared to the non-group affiliated firms with just one exception - client satisfaction. It is not surprising since the unfavourable external settings put stronger pressure on firms headquartered in Poland and operating under the supervision of a parent entity headquartered in Poland. External shocks usually increase the coordination cost that emerges to some extent among networked organizations. The growth of coordination costs can be linked to the fact that the negative external circumstances influence firms directly and indirectly. The direct impact emerges thanks to the firm and external environment entities interactions. The additional indirect impact is related to the networked firms that can absorb and experience the crisis through their relationships with other firms. In this context the relationships can work as a kind of pipeline of external shocks. The impact of negative changes in the external environment can be strengthened by the networked realm in which corporate group affiliates operate. 
The findings are in line with the need to develop and broaden the research on embedded competencies. In the discussion focused on standalone firms the concept of core competencies is used and scholars underline that even firms with similar resources and capabilities can differ in terms of their competitive advantage. We can explain it by referring to the concept of competencies. Competencies are related to the coordination and exploitation of resources and capabilities. Firms differ in terms of their coordination abilities. According to Eriksen and Mikkelsen (1996), we can define competencies as the "organizational capital" that supports a firm's integration of resources into "idiosyncratic value propositions". The coordination directly linked to competencies and the organizational capital is of even greater importance in the case of group affiliated firms that operate within different social and economic ties. The affiliated entities get the chance to increase their competitive advantage thanks to the competencies embedded in the network of a corporate group. The access to the embedded competencies is determined by the relations of particular firms and the structure of the whole network of relations. Thanks to the relations within corporate groups the interactions among group affiliates are not anonymous and the firms can create trustbased relationships (Uzzi, 1999) which further create information transfer and even collaborative attitudes of group affiliates. That can all contribute first to the sources of competitive advantage and second to the performance of the group affiliated firm. Hence we argue that the methodological contribution of this paper is the manifestation of the significance of the concept of embedded competencies. This approach to the upgrading of competitive advantage calls for more conceptual and empirical studies.

Our research is subject to several limitations. Firstly, the theoretical background provides a rather blurry hypothesis on the possible better performance of the firm that is a corporate group affiliate in comparison to the non-affiliated firms. Therefore, we made a simple division in group affiliates (FPGs and FIGs) and non-group affiliates (FNGs). But perhaps a more detailed distinction (e.g. the one suggested by the CSOP and indicated in the introduction to the paper) will help to obtain more transparent and even more unequivocal findings. Secondly, although the study does refer to the manufacturing sector, which is the biggest in terms of the number of companies, at the same time it does neglect all the other industries. It is possible to broaden the scope of our analysis and verify how performance is related to corporate group affiliation in other industries. Additionally it would be useful to conduct the analysis within particular industries to take into account their idiosyncrasies. This would allow for a more detailed insight into the matter.

The limitations of the study suggest that there is a possibility to conduct a more in-depth analysis that would, however, require a much broader scope 
of information. It is also possible to enrich the studies in a cross-country analysis. It would be worth observing, how the relation between the group affiliation and performance evolved in other countries.

\section{Acknowledgement}

The article came into being within a research project financed by the National Science Centre No 2012/07/B/HS4/03050; title: International competitiveness of Polish companies during periods of prosperity and the global economic crisis.

\section{References}

Almeida, P., \& Kogut, B. (1999). Localization of knowledge and the mobility of engineers in regional networks. Management Science, 45, 905-917.

Altomonte, C., \& Rungi, A. (2013). Corporate groups as hierarchies of firms. Determinants of vertical integration and performance. European Central Bank Working Paper Series, 1554.

Balcet, G., \& Bruschieri, S. (2008). Technology Transfer, Joint Ventures and the Emergence of Indian Multinationals: The Case of the Automotive Industry. In B. Andreosso, B. O'Callaghan \& B. Zolin (Eds.), Asia and Europe: Connections and Contrasts (pp. 275-302). Venezia: Ca' Foscarina.

Belenzon, S., \& Berkovitz, T. (2010). Innovation in Business Groups. Management Science, 56(3), 519-535.

Bertrand, M., Mehta, P., \& Mullainathan, S. (2002). Ferreting out tunneling: An application to Indian business groups. Quarterly Journal of Economics, 117, 121-148.

Campbell, D. T., \& Fiske D.W. (1959). Convergent and discriminant validation by the multitrait-multimethod matrix. Psychological Bulletin, 56(2), 81-105.

Carney, M., Gedajlovic, E., Heugens, P., van Essen, M., \& van Oosterhout, J. (2011). Business group affiliation, performance, context, and strategy. A meta-analysis. Academy of Management, 54(3), 437-460.

Central Statistical Office in Poland, 2010, 2011, 2012, 2013, 2014, 2015, Corporate Groups in Poland in 2009, 2010, 2011, 2012, 2013, 2014, Statistical Information and Elaborations, Warsaw.

Claessens, S., Djankov, S., \& Lang, L. H. P. (2000). East Asian corporations: Heroes or villains?. Discussion paper 409, World Bank, Washington, DC

Colpan, A., \& Hikino, T. (2010) Foundations of Business Groups: Towards an Integrated Framework. In A. Colpan, T. Hikino \& J. R. Lincoln (Eds.), The Oxford Handbook of Business Groups (pp. 15-66), Oxford University Press.

Duysters, G, Jacob, J., Lemmens, C., \& Jintian, Y. (2009). Internationalization and Technological Catching Up of Emerging Multinationals: A Comparative Case Study of China's Haier Group. Industrial and Corporate Change, 18(2), 325-349. 
Dyer, J. H., \& Singh, H. (1998). The relational view: Cooperative strategy and sources of interorganizational competitive advantage. Academy of Management Review, 23(4), 660-679.

Dzikowska M., Gorynia M., \& Jankowska B. (2015). Globalny kryzys gospodarczy - próba pomiaru efektów dla poszczególnych krajów. Ekonomista, 6, 733759.

Eisenhardt, K. M., \& Schoonhoven, C. (1996). Resource-based view of strategic alliance formation: Strategic and social effects in entrepreneurial firms. Organization Science, 7, 136-150.

Eriksen, B., \& Mikkelsen, J. (1996). Competitive advantage and the concept of core competence. In: N. J. Foss \& C. Knudsen (Eds.), Towards a competence theory of the firm (pp. 54-74), London: Routledge.

Estrin, S., Poukliakova, S., \& Shapiro, D. (2009), The Performance Effects of Business Groups in Russia. Journal of Management Studies, 46(3), 393420.

Ford, D., Gadde, L.-E., Hakansson, H., \& Snehota, I. (2011). Managing Business Relationships, 3rd ed., Wiley, Chichester UK.

Foss, N. J., \& Eriksen, B. (1995). Competitive advantage and industry capabilities. In C. A. Montgomery (Ed.), Resource-based and evolutionary theories of the firm (pp. 43-69), Boston: Kluwer.

Gourinchas, P. O., \& Kose, A. M. (2011). Economic Linkages, Spillovers, and the Financial Crisis - 2. IMF Economic Review, 59(1), 1-5.

Granovetter, M. (2005). Business groups and social organization. In N.J. Smelser \& R. Swedberg (Eds.), The handbook of economic sociology (2nd ed., pp. 429-450). Princeton, NJ: Princeton University Press.

Gulati R. (1995), Social structure and alliance formation patterns: a longitudinal analysis. Administrative Science Quarterly, 40, 619-652.

Gulati, R. (1999). Network location and learning: The influence of network resources and firm capabilities on alliance formation. Strategic Management Journal, 20(5), 397-420.

Gulati, R., Nohria, N., \& Zaheer, A. (2000). Strategic networks. Strategic Management Journal, 21(3), 203-215.

Keister, L. (2000). Chinese Business Groups: The Structure and Impact of Interim Relations during Economic Development. Oxford University Press.

Khanna, T., \& Yafeh, Y. (2005). Business groups and risk sharing around the world. Journal of Business, 78, 301-340.

Khanna, T., \& Yafeh, Y. (2007). Business groups in emerging markets: Paragons or parasites?. Journal of Economic Literature, 45, 331-372.

Khanna, T., \& Rivkin, J., (1999). Estimating the Performance Effects of Networksin Emerging Markets. Strategic Management Journal, 22, 45-74.

Lavie, D. (2006). The competitive advantage of interconnected firms: An extension of the resource-based view. Academy of Management Review, $31,638-658$. 
Leff, N. (1978). Industrial Organization and Entrepreneurship in the Developing Countries: The Economic Groups. Economic Development and Cultural Change, 26(4), 661-675.

McEvily, B., \& Marcus, A. (2005). Embedded ties and the acquisition of competitive capabilities. Strategic Management Journal, 26, 1033-1055.

Morck, R., Wolfenzon, D., \& Yeung, B. (2005). Corporate governance, economic entrenchment and growth. Journal of Economic Literature, 43, 657-722.

Perotti, E. C., \& Gelfer, S. (2001). Red barons or robber barons? Governance and investment in Russian financial-industrial groups. European Economic Review, 9, 1601-1617.

George, R., \& Kabir, R. (2008). Heterogeneity in business groups and the corporate diversification-firm performance relationship. Journal of Business Research, 65(3), 412-420.

Romanowska, M. (2011). Grupy kapitałowe w Polsce. Strategie i struktury. Polskie Wydawnictwo Ekonomiczne, Warszawa.

Rumelt, R. P. (1984). Towards a strategic theory of the firm. In R. B. Lamb (Ed.), Competitive strategic management (pp. 556-571), Englewood Cliffs, NJ: Prentice-Hall.

Shan, W., Walker, G., \& Kogut, B. (1994), Interfirm cooperation and startup innovation in the biotechnology industry. Strategic Management Journal, 15, 387-394.

Sorensen, H. B., \& Reve, T. (1998). Forming strategic alliances for asset development. Scandinavian Journal of Management, 14(3), 151-165.

Trocki, M. (2004), Grupy kapitałowe. Tworzenie i funkcjonowanie, część II. Wydawnictwo Naukowe PWN, Warszawa.

Todeva, E. (2006). Business Networks. Strategy and Structure. Routledge, Oxon.

Uzzi, B. (1997). Social structure and competition in interfirm networks: The paradox of embeddedness. Administrative Science Quarterly, 42(1), 3567.

Uzzi, B. (1999). Social embeddedness in the creation of financial capital. American Sociological Review, 64, 481-505.

Williamson, O.E. (1975). Markets and Hierarchies: Analysis and Antitrust Implications. New York, Free Press.

Williamson, O.E. (1985). The Economic Institutions of Capitalism. New York, FreePress.

World Development Indicators. Retrieved from http://databank.worldbank. org/data/home.aspx

Wernerfelt, B. (1984). A resource-based view of the firm. Strategic Management Journal, 5(2), 171-180. 


\section{Abstract (in Polish)}

Grupy kapitałowe sq szczególnym przypadkiem powiqzań sieciowych, które mogq stanowić źródło przewagi dla firm. Pozwalaja jednostkom obniżyć koszty, tworzq dodatkowe źródła zasobów, zwiększajq elastyczność operacji i odpowiedzi na turbulencje w gospodarce, co jest szczególnie istotne w czasach kryzysu gospodarczego. Istota niniejszej publikacji jest zbadanie wpływu uczestnictwa w grupie kapitałowej na szeroko rozumianq konkurencyjność firmy. Pierwszym celem jest porównanie, czy firmy należq̨ce do grupy kapitałowej wykazywały wyższq konkurencyjność czynnikowq. Po drugie weryfikujemy, czy podobna relacja była widoczna w przypadku wyników osiqganych przez te firmy. Badanie zostało zaprojektowane na podstawie pogłębionych badań literaturowych i przeprowadzone za pomoca metody CATI. W jego wyniku weryfikujemy hipotezę, że im wyższa konkurencyjność czynnikowa firmy w czasie kryzysu tym lepszq osiaga ona pozycję konkurencyjnq. Badania empiryczne przeprowadzono na ponad 700 firmach sektora produkcyjnego w Polsce w czasie trwania kryzysu i krótko po jego zakończeniu. $W$ analizie wykorzystano analizę klastrowq, testy nieparametryczne i analizę korelacji.

Słowa kluczowe: grupy kapitałowe, kryzys ekonomiczny, efektywność, współpraca sieciowa.

\section{Biographical notes}

Marlena Dzikowska, PhD is an Assistant Professor at the Poznan University of Economics - Department of International Competitiveness. Her main research areas include the international competitiveness of firms and industries, global sourcing and value chains of MNEs.

Marian Gorynia, PhD is a Professor at the Poznan University of Economics Department of International Competitiveness and a member of numerous international scientific organizations. His main research areas include the international competitiveness of firms and industries, foreign direct investments and the internationalization of firms and industries.

Barbara Jankowska, PhD is an Associate Professor at the Poznan University of Economics, the Head of Department of International Competitiveness. Her main research areas include the international competitiveness of firms and industries, with particular emphasis on SMEs and creative industries, business clusters, competition and cooperation strategies of firms, and the internationalization of firms and industries.

Katarzyna Mroczek-Dąbrowska, PhD is an Assistant Professor at the Poznan University of Economics - Department of International Competitiveness. Her main research areas include the international competitiveness of firms and industries, transaction costs and the internationalization levels of industries. 